\title{
HISTOLOGY OF THE TESTIS AND THE EPIDIDYMAL DUCTS FROM HOARY FOX Lycalopex vetulus (LUND, 1842)
}

\author{
HISTOLOGIA DOS TESTÍCULOS E DUCTOS EPIDIDIMÁRIOS DA RAPOSA-DO- \\ CAMPO Lycalopex vetulus (LUND, 1842)
}

\section{Mahmoud MEHANNA ${ }^{1}$; André Luís Souza FERREIRA ${ }^{\mathbf{1}}$; Adelina FERREIRA ${ }^{\mathbf{1}}$; Regina Célia Rodrigues da PAZ ${ }^{2}$; Thaís Oliveira MORGADO ${ }^{3}$}

1. Laboratório de Análises Morfológicas e Morfométricas, Instituto de Biociências, Universidade Federal de Mato Grosso - UFMT; 2. Laboratório de Pesquisa em Animais de Zoológico - LPAZ, Faculdade de Medicina Veterinária Universidade Federal de Mato Grosso UFMT; 3. Doutoranda do Programa de Pós-Graduação em Ciências Veterinárias - PPGVET, Faculdade de Medicina Veterinária UFMT

\begin{abstract}
The hoary fox Lycalopex vetulus (Lund, 1842) is a small canid, endemic to Brazil, belonging to the Canidae family, widely distributed in the country, occurring records in different regions and habitats. The objective of this study is to describe morphologically the testicles and epididymal ducts of hoary fox. The animals, coming from the zoo of Federal University of Mato Grosso, Brazil, had died by natural causes. The male reproductive system was dissected to collect the testicles. The samples were fragmented and histologically examined. Microscopically, the testes were coated by the vaginal and albuginea tunic, formed by modeled dense connective tissue with large amount of collagen fibers. Into the organ, convoluted seminiferous tubules were surrounded by a basement membrane characterized by the presence of myoid and Sertoli cells and germinative epithelium composed by Between the seminiferous tubules, interstitial tissue composed of connective tissue, blood and lymph vessels and Leydig cells in polyhedral shape was present. The epididymal ducts showed pseudostratified columnar epithelium with secretory cells, in which stereocilia located on a basement membrane filled by myoid cells were found. The structures observed by us are very similar to those described for other mammals.
\end{abstract}

KEYWORDS: Morphology. Reproductive system. Male. Canid.

\section{INTRODUCTION}

The canids, being at the top of the food chain. They have great ecological importance, so that can regulate the population of natural prey and may influence the entire ecosystem dynamics in living. In the absence of predators, prey tend to multiply exponentially and can cause serious damage at all trophic levels of the food chain (PITMAN et al., 2002).

Carnivores has been constant victims of all pressure forms, such as the systematic elimination of animals that are causing economic losses to farmers, poaching for trophy, poaching for sale of skins, livestock trade, distortion and fragmentation of habitats (PITMAN et al., 2002). Thus, although there is the conservation and management of canine populations in the wild, there is still the need to maintain some species in captivity in order to reintroduce the pups born to the nature, aiming to prevent the extinction of these species.

The Lycalopex vetulus, popularly known as hoary fox, little fox or little fox of the field, is a species of the Canidae family, whose Lycalopex gender, consists of six species, two of which L. gymnocercus and L. vetulus - occur in Brazil (WILSON; REEDER, 2005).
Considering the new information, the current area of occurrence of the hoary fox, endemic species from Brazil, extends from the northeastcenter and west of the São Paulo state, north of Piauí and medium-east of Maranhão, south-center of Mato Grosso, Mato Grosso do Sul (dry areas and not flooded of Pantanal), south of Rondônia, Goiás, Tocantins, Distrito Federal, southwest of Bahia, and Midwest of Minas Gerais (DALPONTE, 2003; DALPONTE 2009; COSTA; COURTENAY, 2003; LEMOS; AZEVEDO, 2009; LEMOS et al, 2013).

Regions where there Lycalopex vetulus records include different habitats with open formations of the Cerrado, including areas of savanna vegetation with scattered trees, vegetation types of clean fields, dirty fields, savanna and cerrado stricto sensu, as well as denser or forests formations, whether deciduous and gallery forests (LEMOS et al., 2013).

The Hoary fox is the smallest canid of South America, whose body length varies $49-71 \mathrm{~cm}$, tail $25-38 \mathrm{~cm}$, reaching weight up to $4.0 \mathrm{~kg}$. Presents short snout, large ears and variation in color of the coat, which follows the light gray on the dorsal region of the body and yellow brown to brown on the bottom, including the neck and behind the ears parts the lower jaw is dark and the tail is bushy with 
dense hair and may have a dark spot on the dorsal surface (DALPONTE; COURTENAY, 2004).

Hoary fox presents crepuscular, nocturnal and terrestrial habits, living alone, in pairs or in small family units (NOWAK, 1999; LEMOS; FACURE, 2011). It is a carnivore, feeds mainly on small vertebrates, birds, reptiles and insects like termites and locusts, and fruits (CABRERA; YEPES, 1960; DALPONTE, 1997; DALPONTE; COURTENAY, 2004).Gestation lasts about 50 days, the number of pups per litter is two to five and are usually born from july to august (LEMOS et al., 2013).

Knowledge of the reproductive biology of this species is of paramount importance for the correct management of their stock, especially in its basic aspects, so many studies can be performed using them as a biological model for the physiology of reproduction, especially for endangered species extinction (WILDT et al. 1986), where Lycalopex vetulus is listed as Vulnerable by the national Red Lists of Argentina, Bolivia and Brazil. In the IUCN (International Union for Conservation of Nature and Natural Resources) Red List of Threatened Species (2015) is listed by Near Threatened (ND) with population trend decreasing (Dalponte; Courtenay, 2008).

In this sense, studies related to the male gonads of Lycalopex vetulus has scientific relevance, particularly in morphology, since there are few data in the histologic literature of canine testicles. Therefore, this study aimed to describe morphologically the testicles and epididymal ducts of hoary fox, offering results that might be useful in relation to reproduction of this species.

\section{MATERIAL E METHODS}

For this work we used a male hoary fox specimen, Lycalopex vetulus, coming from the zoo, who had died by natural causes in the Veterinary Hospital of the Federal University of Mato Grosso, Cuiabá Campus.

In order to carry out the histological analysis, the male reproductive tract was dissected to collect the whole testis and the epididymis, observing the arrangement of the organs. The samples taken were fragmented into four parts, with distal and medial to the right and left testicles. Subsequently they were dehydrated in alcohol at $70 \%$ and $95 \%$ and embedded in glycol methacrylate type plastic resin, and brought to the microtome Leica RM2125 RTS where they were cut to a thickness of $3 \mu \mathrm{m}$ and stained with aqueous $1 \%$ toluidine blue. And, finally, they were sent to photo documentation, microscopic analysis in Leica DM750 and description of structures.

\section{RESULTS}

The male reproductive system of the hoary fox consists of the testicles, epididymis, genital ducts, accessory glands, penis and prepuce.

The testes are paired organs of oval to rounded, located outside the abdominal cavity, in a skin fold called the scrotum, responsible for the production of sperm and secretion of male sex hormones, especially testosterone. This testicular location is important because need a temperature below the abdominal temperature to maintain testicular function. The coloration follows from white to yellow and is surrounded by a capsule called the tunica albuginea, consisting of dense connective tissue.

Microscopically, the tunica albuginea examined in $L$. vetulus testis appeared thick, formed by modeled dense connective tissue with great amount of collagen fibers, arranged parallel to each other, giving greater strength and low elasticity tissue. This is thickened on the dorsal which forms the mediastinum testis (axial range of connective tissue) sending fibrous septa into the organ by dividing it into compartments called testicular lobes. Beyond that, testicular arteries and veins enter this capsule, demonstrating a highly vascularized tissue. The tunica albuginea is covered by the visceral layer of the tunica vaginalis, consists of connective tissue with fibroblasts and blood vessels (Figure 1).

The seminiferous tubules, the most abundant component of the testicular parenchyma, consists of spermatogenic cells (which give rise to sperm) and Sertoli cells, surrounded by a basement membrane and connective tissue formed by fibroblasts (Figure 2).

Adjacent to the basement membrane, there is the presence of flattened myoid cells and immature germ cells termed spermatogonia, these were located in the basal part of the seminiferous epithelium as round cells with oval nuclei and one or more evident nucleoli. These cells form primary spermatocytes, which appear as large, rounded cells with nucleus and evident nucleolus, and being situated close to the basal membrane. The secondary spermatocytes appear in sequence, and have lower compared to primary spermatocytes, these originate the early spermatids, round cells with little stained nuclei. After these cell stages, the final spermatids appear darker, small, oval and / or elongated with 
the presence of long tails projecting into the lumen of the seminiferous tubules and sperm (Fig. 3).

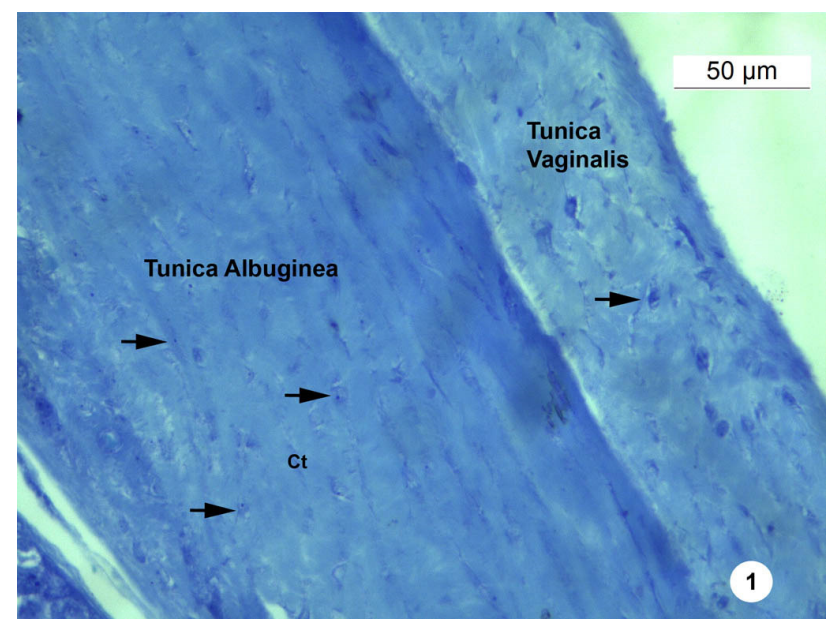

Figure 1. Vaginal and albuginea tunic, Connective tissue (Ct). Toluidine blue, obj. 40x;

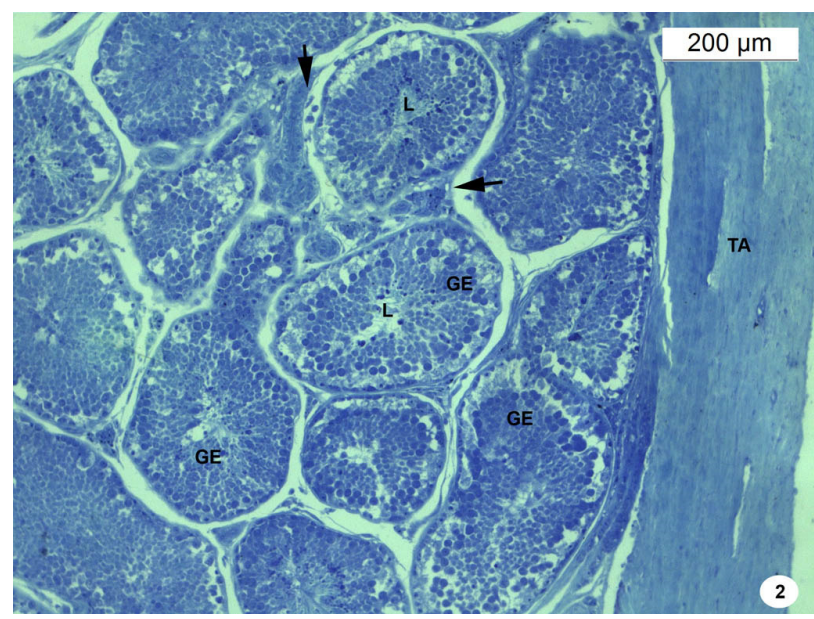

Figure 2. Seminiferous tubules of the testis. In some tubules are shown the germinal epithelium (GE), the lumen of the tubules (L) and the tunica albuginea (TA); In space between the tubules exists the interstitial tissue (arrows). Toluidine blue, obj. 10x.

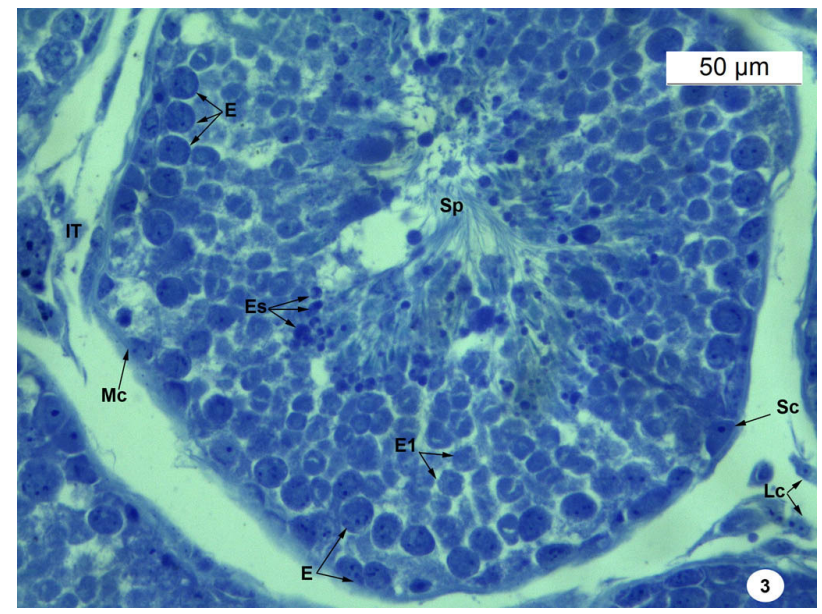

Figure 3. Seminiferous tubules of the testis. Note Myoid cells (Mc), interstitial tissue (IT); Sertoli cell (Sc); Spermatogonia (E); Primary spermatocytes (E1); Spermatids (Es); sperm (Sp) and Leydig cells (Lc). Toluidine blue, obj. 40x; 
The Sertoli cells are less evident, distinguished by a more elongated or pyramidal form, irregularly contours and extending from the basement membrane, which are adhered, to the tubule lumen, and the nuclei appear spherical to oval with a prominent nucleolus and highly stained (Fig. 3).

Filling the space between the seminiferous tubules, there is the interstitial tissue consisting of loose connective tissue presenting fibroblasts, blood and lymph vessels, and Leydig cells, the main component of intertubular compartment, in lesser quantities, having polyhedral shape with different sizes, bright nuclei and evident nucleoli (Fig. 3).

Analyzing microscopically, the Lycalopex vetulus epididymis, it was found that is surrounded by a thick tunica albuginea and dense connective tissue, covered by the visceral layer of the tunica vaginalis (Figure 4).

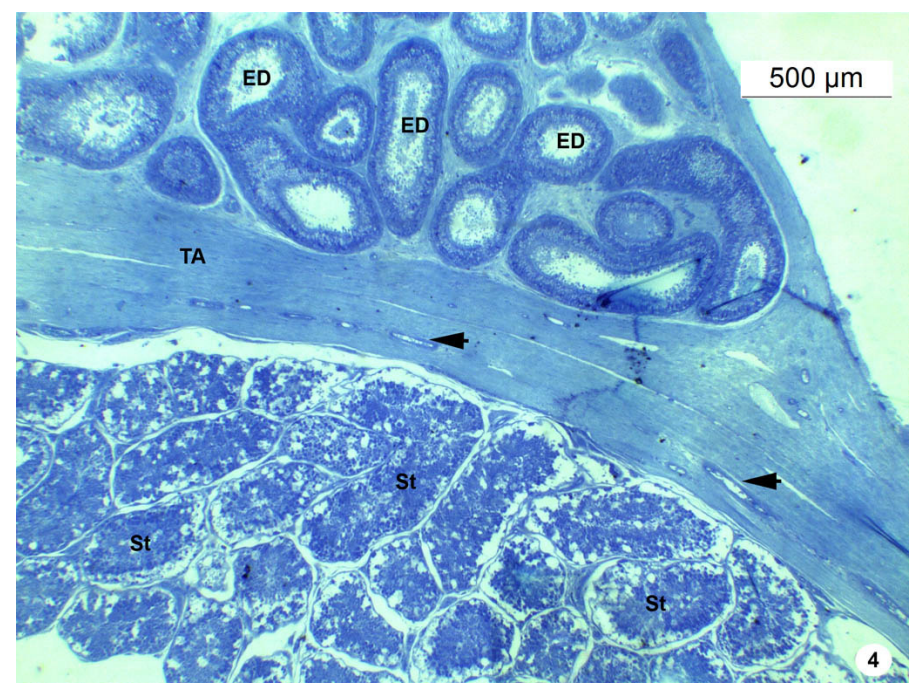

Figure 4. Seminiferous tubules (St) and epididymal ducts (ED) separated by Tunica albuginea (TA), with presence of blood vessels (arrows).

The epididymal ducts (Figure 5) are lined by a pseudostratified columnar epithelium with secretory cells of which stereocilia design. This epithelium is on a delicate basement membrane and integrated by myoid cells (flat cells with obvious nucleus) in its structure.

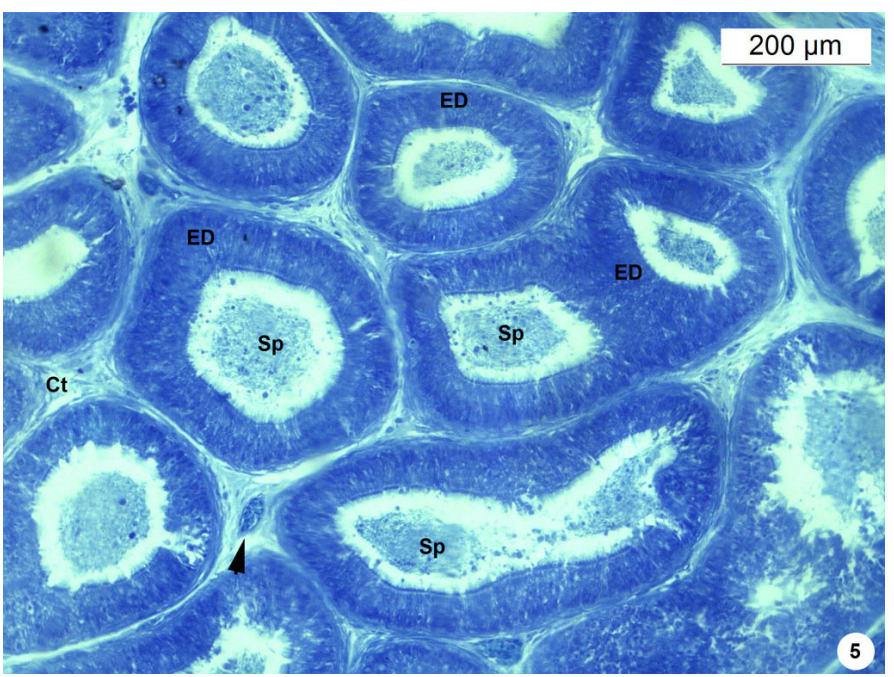

Figure 5. Epididymal. In some ducts are marked the presence of sperm (Sp); Epididymal Ducts (ED); Blood vessels (arrow). In the space between the ducts there is connective tissue (Ct). Toluidine blue, obj. 10x; 


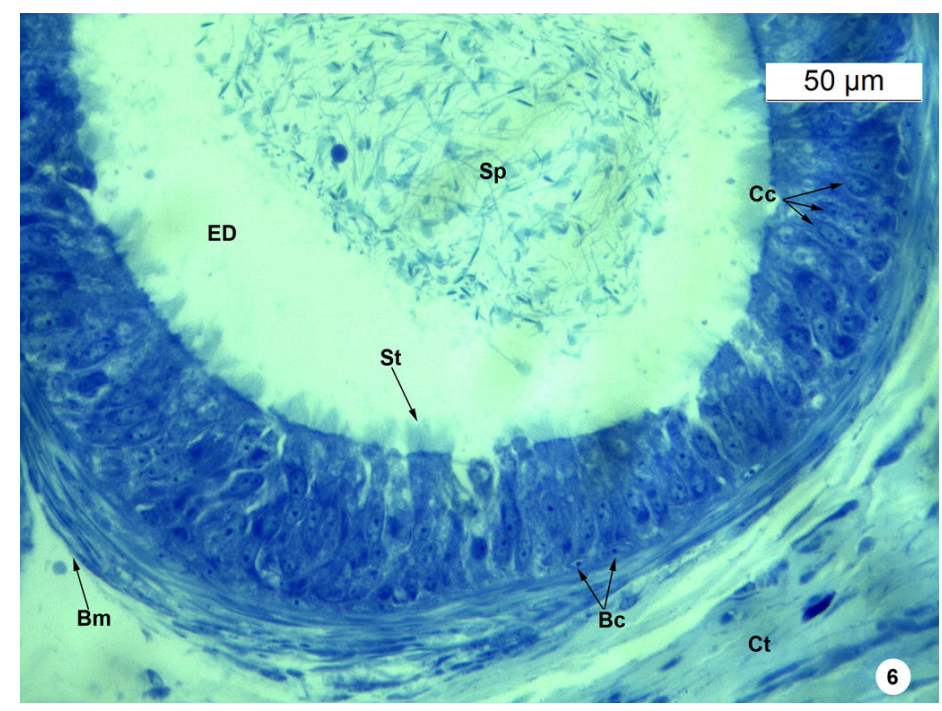

Figure 6. Epididymal Duct (ED); Basal cells (Bc); Columnar cells (Cc); Stereocilia (Ec); Basement membrane $(\mathrm{Bm})$; Connective tissue (Ct); Sperm (Sp). Toluidine blue, obj. 40x.

The cells of the epididymal duct epithelium are represented by principal or columnar cells and basal cells. The principal cells presenting in large numbers and are covered with long branched stereocilia with elongated nuclei and distinct nucleoli. The round or oval basal cells are irregularly shaped nuclei and may be extended or elliptical and nucleoli are conspicuously peripheral (Figure 6).

The epididymal duct is surrounded by a tissue called peritubular stroma, which is composed of an arrangement of collagen fibers with fibroblasts, fibrocytes and smooth muscle cells, and is highly vascularized, standing outside the basement membrane of the duct. Inside of the duct lumen it was found some material, probably represented by cellular scrubs or residual bodies and sperm. Long stereocilia protude from the cylindrical cells to the full extent of the epithelium (Fig. 6).

\section{DISCUSSION}

On histological analysis of the testes of hoary fox Lycalopex vetulus (Lund, 1842), it was evident the presence of a thick capsule called the tunica albuginea, consisting of dense modeled connective tissue with the presence of fibroblasts and lot of collagen fibers. Dellman \& Wrobel (1982) reported the same pattern of tunica albuginea in dogs and sheep, presenting as a thin layer of dense connective tissue, filled with collagen fibers, elastic fibers and fibrous septa, and artery branches and testicular vein.
The seminiferous tubules are formed by columnar epithelium consisting of spermatogenic cells and Sertoli cells, surrounded by a basement membrane, separated by interstitial tissue. According Bacha \& Bacha (2003), combinations of spermatogenic cells of the epithelium development occur inside a seminiferous tubule, in which these cellular stages occupy a portion of each tubule.

In this sense, the germinal epithelium of the seminiferous tubules of hoary fox showed a segment to which it showed spermatogonia which, according to Junqueira and Carneiro (2013) are relatively small cells, measuring about 12 micrometers $(\mu \mathrm{m})$ in diameter, and when development are associated with the great Sertoli cells in mammals (GARNER; HAFEZ, 2004). The daughter cells can continue dividing, remaining as stem cells or differentiated itself during successive division cycles into primary spermatocytes (JUNQUEIRA; CARNEIRO, 2004) and subsequently in secondary, and many round spermatids and/or elongated, leading to formation of sperm.

Caldeira (2007) reports on morphofunctional analysis of the testis and spermatogenic process of the crab-eating fox (Cerdocyon thous, Linnaeus, 1766) that spermatogenesis is a synchronous and regular process of differentiation and cell division, whereby a spermatogonia gradually differentiates a highly specialized haploid cell, the sperm. This differentiation involves three phases, according to morphological and functional considerations: (1) the proliferative phase (spermatogonia) in which the 
cells undergo successive mitotic divisions; (2) meiotic phase (spermatocytes) and (3) differentiation phase (spermatids), in which the spermatids undergo changes, turning into sperm (COROUT et al., 1970 cited BOILER, 2007). These data corroborate the spermatogenic process that occurs in testis of Lycalopex vetulus where spermatogenic developmental sequence occurs similarly to Cerdocyon thous.

The germ cells throughout the seminiferous epithelium, are supported and organized by the Sertoli cell (Russell et al., 1991), which plays a fundamental role in the mediation of FSH and testosterone in the spermatogenic process in the support and nutrition of the developing germ cells, in compartmentalization of the seminiferous epithelium in the release of sperm in the tubule lumen in fluid secretion and phagocytosis germ cell in degeneration and excess cytoplasm of spermatids in spermiogenesis (RUSSEL; GRISLWOLD, 1993; FRANCE; Russel, 1998; BALARINI , 2008).

The interstitial tissue of the testis located in the intertubular compartment, it is important for nutrition of the cells of seminiferous tubules, transporting hormones and androgen production. The spaces between the seminiferous tubules of the testes are filled with connective tissue, blood and lymph vessels, and Leydig cells or interstitial cells, the main components of this compartment (JUNQUEIRA; CARNEIRO, 2013). The same components were found in both morphological study of testicular Lycalopex vetulus and Cerdocyon thous (Linnaeus, 1766), which Caldeira (2007) discusses the connective tissue is the most abundant intertubular tissue, representing an average $7.95 \%$ of testicular parenchyma, while the puma (Puma concolor, Linnaeus, 1771) was observed $9.5 \%$ of testicular parenchyma allocated in connective tissue (GUIÃO-LEITE, 2002).

In canids, interstitial cells and Leydig cells are present in intertubulares spaces, but to a lesser extent than observed in cats, along with the connective tissue; have polyhedral shape with large spherical nucleus and evident nucleolus; the cytoplasm is acidophilus and contains numerous granules and lipid droplets (DIAGONE, 2009).

These results are similar to observations of Hoshino et al, (2002), which recounts in his studies of morphological analysis of dog testicles, the same standard of testicular structures of Lycalopex vetulus: the tunica albuginea, which is thick and constituted by dense connective tissue and rich collagen fibers, seminiferous tubules formed by three compartments, (I) the interstitial, which surrounds the tubules and contains connective tissue with various cell types, including interstitial or Leydig cells, (II) the basal, inside of the tubules, between the basal membrane and the junctional complexes of Sertoli cells, which containing these cells and spermatogonia, and (III) the luminal, corresponding to the central part of the tubule, internal processes of Sertoli cells and other spermatogenic cells of the epithelium.

The epididymis in mammals is considered a very important segment in extra-testicular sperm route. It is an extremely coiled tube which forms a compact mass intimately inserted along the dorsolateral surface of the testicle. It is divided into head, body and tail of the epididymis, and is the primary local of maturation and storage of sperm, in addition to being the location where the sperm obtain mobility (FOSTER, 2007). This description does not differ from the observations made in Lycalopex vetulus where the epididymis provides structure similar to other mammals.

In this sense, Schimming et al. (2002) presents morphological data epididymal ducts of dogs near to the hoary fox, where the epididymal duct is lined by pseudostratified columnar epithelium with cell population consisting of principal cells, basal and apical, present in all regions. This epithelium is surrounded by connective tissue constituted by collagen fibers and fibroblasts. And, according to Hoshino et al. (2002), domestic cats also show the same pattern of cell structures of epididymal epithelium.

\section{CONCLUSIONS}

The structure of the Lycalopex vetulus testis showed a similar pattern to that described for other mammals as domestic dogs Canis lupus, (Linnaeus, 1758), both in their macro and microscopic aspects.

The male individuals of Lycalopex vetulus have the testicle contituted by a capsule called tunica albuginea with collagen fibers and fibroblasts, tubules seminíferos with well developed stratified epithelium with presence and absence of light, evident support cells or Sertoli presenting irregular shape, developed intertubular or interstitial tissue and vascular compartments with Leydig cells.

The epididymal ducts showed columnar epithelium pseudostratified standing on a basement membrane filled by myoid cells. This epithelium has different cells, whose cylindrical cell design stereocilia toward the lumen of the epididymal duct, whose interior duct light found sometimes some 
material, probably represented by cellular scrubs or residual bodies and sperm.

\section{ACKNOWLEDGEMENTS}

Thanks to CAPES for financial support.

RESUMO: A raposa-do-campo Lycalopex vetulus (Lund, 1842) é um canídeo de pequeno porte, endêmico do Brasil, pertencente a família Canidae, com ampla distribuição no país, ocorrendo registros em várias regiões e habitats diferentes. Com base nessa informação, o objetivo deste trabalho é caracterizar morfologicamente os testículos e ductos epididimários da raposa-do-campo. O animal, oriundo do zoológico da Universidade Federal de Mato Grosso, Brasil, veio a óbito por causas naturais e o sistema reprodutor masculino foi dissecado para coleta dos testículos. As amostras retiradas foram fragmentadas e histológicamente examinadas. A partir das análises microscópicas dos testículos foram identificados: a túnica vaginal e albugínea, formada por tecido conjuntivo denso modelado, com grande quantidade de fibras colágenas; túbulos seminíferos enovelados e revestidos por epitélio germinativo e células de Sertoli, envolvidos por uma membrana basal com presença de células mioides; tecido intersticial entre os túbulos seminíferos constituído de tecido conjuntivo, vasos sanguíneos e linfáticos, e células de Leydig em formato poliédrico. Os ductos epididimários apresentaram epitélio cilíndrico pseudoestratificado com células secretoras dos quais projetam estereocílios, situados sobre uma membrana basal repleta por células mióides. As estruturas por nós observadas possuem muita semelhança com as demais descrições para mamíferos.

PALAVRAS-CHAVE: Morfologia. Sistema reprodutor. Macho. Canídeo.

\section{REFERENCES}

BACHA JR., W. J.; BACHA, L. M. Male reproductive system. Coloured Atlas of veterinary histology. 2. ed. Sao Paulo: Roca, p. 335-336, 2003.

BALARINI, M. K. Morphofunctional evaluation of testis and spermatogenic process cat-to-killsmall (Leopardus tigrinus Schreber, 1775) Adult. Master's Graduate in Veterinary Medicine, Viçosa, MG, 2008.

BANKS, W. J. Male reproductive system. Applied Veterinary Histology, São Paulo: Manole, p. 546-556, 1992.

CABRERA, A.; YEPES, J. Mammals Sud Americans. 2 ed. Editors movie edit. p. 1-187, 1960.

CALDEIRA, B. C. Assessment of morphofunctional testis and spermatogenic process of the crab-eating fox (Cerdocyon thous, Linnaeus, 1766) adult. Master's thesis, Viçosa: Federal University of Viçosa, 2007. COROUT, M.; HOCHEREAU-DE-REVIERS, M. T; ORTAVANT, R. Spermatogenesis. In: JOHNSON, AD; GOMES, W. R; VANDEMARK, N. L (eds). The testis. New York: Academic Press. p. 339-432, 1970.

COSTA, CHN; COURTENAY, O. A new record of the hoary fox Pseudalopex vetulus in north Brazil. Mammalia, 67: p. 593-594, 2003.

DALPONTE, J. C. Diet of hoary fox, Lycalopex vetulus, in Mato Grosso, Brazil. Mammalia, v. 61, n. 4, p. 537-546, 1997.

DALPONTE, J. C. Natural history, behavior and conservation of the hoary fox, Pseudalopexvetulus (Canidae). Thesis (PhD in Animal Biology). University of Brasilia. p. 179, 2003.

DALPONTE, J. C. Lycalopex vetulus (Carnivora: Canidae). Mammalian Species, 847: p. 1-7, 2009. https://doi.org/10.1644/847.1

DALPONTE, J.; COURTENAY, O. Hoary fox Pseudalopex vetulus (Lund, 1842), p. 72-76. In: Sillero-Zubiri, C., Hoffmann, M. \& Macdonald, DW (eds.). Canids: Foxes, Wolves, Jackals and Dogs: survey Status and conservation action plan. IUCN. P. 430, 2004. 
DALPONTE, J.; COURTENAY, O. 2008. Lycalopex vetulus. The IUCN Red List of Threatened Species 2008: https://doi.org/10.2305/IUCN.UK.2008.RLTS.T6926A12815527.en

DELLMANN, H.; WROBEL, K. Male reproductive system, In: DELLMANN, H., BROWN IN Veterinary Histology, Guanabara Koogan SA, Cap 12, p. 232-253, Rio de Janeiro, in 1982.

DIAGONE, K. V. Histology and morphometry of adult domestic cats testicles. Faculty of Agricultural and Veterinary Sciences - Unesp. Jaboticabal, São Paulo, 2009.

FOSTER, R. A. Male Reproductive System. In McGavin MD \& Zachary J. F. (Eds.), Veterinary PathologicBasis of Disease (4th ed, pp 1317 - 1349). Missouri St. Louis: Mosby Elsevier, 2007.

FRANCE, L.R; RUSSELL, L.D. The Testis of Domestic Animals. In: Martinez-Garcia, F \& Regadera, J. (Eds.). Male Reproduction: A Multidisciplinary Overview. Churchill Livingstone, Madrid, p. 197-219, 1998.

GARNER, D. L.; HAFEZ, E. S. E. Sperm and seminal plasma. In: Animal reproduction, 7th ed, São Paulo: Manole, p. 97-106, 2004.

GUIÃO-LEITE, F. L. Morphological analysis of testis and spermatogenic process of puma (Puma concolor) adult. Master's thesis, Viçosa: Federal University of Viçosa, 2002.

HOSHINO, P.; NAKAGHI, L. S. O.; PACHECO, M. R.; LUI, J. F; MALHEIROS, E. B. morphometry of the seminiferous tubules and epididymal ducts of dogs and cats from neutering surgery. Biotemas, Florianópolis, v. 15, n. 1, p. 97-110, 2002.

JUNQUEIRA, L. C.; CARNEIRO, J. Male reproductive apparatus. Basic histology. Rio de Janeiro: Guanabara Koogan, 10th ed., p. 414-430, 2004.

JUNQUEIRA, L. C.; CARNEIRO, J. Basic Histology. 12th Ed Rio de Janeiro: Guanabara Koogan, p. 412-424, 2013.

LEMOS, F. G.; AZEVEDO, F. C. Lycalopex vetulus (Lund, 1842). p. 61. In: Bressan, PM; Kierulff, MCM \& Sugieda, AM (eds.). Endangered wildlife in the State of São Paulo - vertebrates. Sao Paulo: ParqueZoológico Foundation of São Paulo / Department of the Environment. p. 645, 2009.

LEMOS, F. G; AZEVEDO, F. C.; BEISIEGEF, B. M; JORGE, R. P. S.; PAULA, R. C.; RODRIGUES, F. H. G.; RODRIGUES, L. A. Evaluation of the risk of extinction of the fox of the field Lycalopex vetulus (Lund, 1842) in Brazil. Brazilian biodiversity, v. 3, n. 1, p. 160-171, 2013.

LEMOS, F. G.; FACURE, K. G. Seasonal variation in foraging group size of crab-eating foxes and hoary foxes in the Cerrado biome, Central Brazil. Neotropical Mammalogy, v. 18, n. 2, p. 239-245, 2011.

MILLER, B.; RABINOWITZ, A. Why Conserve Jaguar? In Medellin, RA; Chietkiewicz C; Redford, KH; Robinson, JG; Andreson, E \& Taber, EA (Eds.) El Jaguar en el Nuevo Milenio. Mexico: Universidad Nacional Autonoma de Mexico / Wildlife Conservation Society, 2002.

NOWAK, R. M. Walker's Mammals of the World. 6th ed. v. 1 and 2. Baltimore: The John Hopkins University Press, 1999.

PITMAN, M. R. P. L.; OLIVEIRA, T. G.; PAULA, R. C.; INDRUSIAK, C. Manual identification, prevention and control predation by carnivores. Brasilia. Issues: IBAMA, 2002.

RUSSELL, L. D.; ETTLIN, R. A.; SINHA HIKIN, A. P.; CLEGG, E. D. Histological and Hispopathological Evaluation of the Testis. Clerewater, f. 1, Cache River Press, p. 286, 1991. 
RUSSELL, D.; GRISWOLD, M. D. The Sertoli Cell. Cache River Press, Clearwater, Florida, p. 801, 1993.

SCHMMING, B. C; VICENTINI, C. A.; TIRAPELLI, L. F.; TIRAPELLI, D. P.C. Morphological examination of the epididymal duct in the dog. Brazilian Journal of Veterinary Research and Animal Science, São Paulo, v. 39, n. 2, p. 61-65, 2002.

WILDT, D. E.; SCHIEWE, M. C.; SCHMIDT, P. M.; GOODROWE, K. L.; HOWARD, J. G.; PHILLIPS, L. G.; O'BRIEN, S. J.; BUSH, M. Developing systems model animal is embryo technologies in rare and endangered wildlife. Theriogenology, v. 25: p. 33-35, 1986. https://doi.org/10.1016/0093-691X(86)90182-2

WILSON, D. E.; REEDER, D. M. Mammal Species of the World. Johns Hopkins University Press. Baltimore. v. 2, p. 142, 2005. 